\title{
A Genetic Polymorphism (rs17251221) in the Calcium-Sensing Receptor is Associated with Breast Cancer Susceptibility and Prognosis
}

\author{
Xiaoyan Lia Xiangnan Kong ${ }^{\mathrm{a}}$ Liyu Jiang ${ }^{\mathrm{a}}$ Tingting Ma ${ }^{\mathrm{a}}$ Shi Yan ${ }^{\mathrm{b}}$ Cunzhong Yuan ${ }^{\mathrm{b}}$ \\ Qifeng Yang ${ }^{\mathrm{a}, \mathrm{c}}$ \\ aDepartment of Breast Surgery, Qilu Hospital, Shandong University, 'D Department of Obstetrics and \\ Gynecology, Qilu Hospital, Shandong University, 'Department of Pathology Tissue Bank, Qilu Hospital, \\ Shandong University, Jinan, Shandong, P.R. China
}

\author{
Key Words \\ Calcium-sensing receptor $•$ Breast cancer $\bullet$ Susceptibility $\bullet$ Prognosis
}

\begin{abstract}
Background: Calcium-sensing receptor (CaSR) is a typical G protein coupled receptor. The rs17251221 SNP is located in an intron of the CaSR gene, and the G allele is considered a gain of function mutation. Previous studies revealed that rs17251221 polymorphisms contribute to the risk of developing certain types of cancers. This study investigated the rs17251221 SNP in breast cancer by analyzing the correlation of the rs17251221 genotype with breast cancer susceptibility, clinicopathological features and prognosis. Methods: A TaqMan assay was used to genotype the rs17251221 SNP in a case-control study. The expression levels of CaSR in breast cancer tissues were determined using quantitative reverse-transcription PCR ( $q R T-P C R$ ) and western blot analysis. The association of the rs17251221 genotype and the clinicopathological characteristics, as well as the prognosis of the breast cancer patient, was assessed statistically. Results: We found that the AG and GG genotypes were associated with lower mRNA and protein levels of CaSR compared to the AA genotype in breast cancer tissues. We also found that the AG and GG genotypes were associated with breast cancer susceptibility, the patient's age at diagnosis, tumor size, lymph node metastasis and estrogen receptor status of breast cancer tissue. More importantly, we found that the genotypes were prognostic markers for both disease-free survival and overall survival of breast cancer. Conclusion: The rs17251221 SNP is a risk factor associated with breast cancer susceptibility, as well as a prognostic indicator. Our data suggest that rs17251221 may be a potential therapeutic target in breast cancer.
\end{abstract}

Copyright (C) 2014 S. Karger AG, Basel 
Li et al.: Rs17251221 is Associated with Breast Cancer Susceptibility and Prognosis

\section{Introduction}

Breast cancer is a major public health problem worldwide. Though the mortality rate of breast cancer has decreased due to improvements in early detection and/or treatment, approximately 234,580 new breast cancer cases are expected to be diagnosed in 2013, and approximately 40,030 patients will die from breast cancer [1]. Breast cancer is a heterogeneous disease that is influenced by both genetic and environmental factors. Genetic single nucleotide polymorphisms (SNPs) are important indicators of susceptibility to breast cancer [2,3]. Studies have confirmed that the existence of genetic mutations, such as those in the BRCA1 and BRCA2 genes, are highly associated with breast cancer risk [4, 5]. Therefore, identification of additional potential markers may result in the increased prediction of breast cancer susceptibility and allow for the earlier application of appropriate therapeutic strategies to reduce mortality.

Calcium-sensing receptor (CaSR) was first cloned from the bovine parathyroid gland by Brown and his colleagues in 1993 [6]. Subsequently, the gene was mapped to chromosome $3 q 13$ [7]. CaSR is a typical G protein coupled receptor with an extracellular domain, a 7 membrane spanning domain and an unusually long intracellular carboxyl terminal tail. The receptor is glycosylated in the endoplasmic reticulum, modified in the Golgi and is finally localized to the plasma membrane [8-10]. CaSR plays an important role in calcium homeostasis through the regulation of parathyroid hormone secretion and calcium reabsorption [8]. The rs17251221 SNP is located in an intron of the CaSR gene, and the G allele is considered a gain of function mutation. Genome wide meta-analysis revealed that the rs17251221 SNP was strongly associated with serum calcium regulation in individuals of European and Indian-Asian descent [11]. A previous study found that an inactivating mutation of CaSR (rs17251221) caused familial hypocalciuric hypercalcemia, which results in life-long hypercalcemia and leads to asymptomatic life-long hypercalcemia [12]. Chou et al. [13] revealed that the rs17251221 SNP was a susceptibility marker for stone multiplicity in nephrolithiasis. Recently, it was reported that the rs17251221 SNP was strongly associated with prostate cancer [14]. However, the genetic effect of CaSR (rs17251221) on the susceptibility and prognosis of breast cancer is still unclear. In this manuscript, we evaluated the association of the rs17251221 polymorphism with breast cancer susceptibility, clinicopathological variables and prognosis.

\section{Patients and Methods}

\section{Patients and samples}

This study involved 217 breast cancer patients who were diagnosed at Qilu Hospital of Shandong University between 2001 and 2011. All of the diagnoses were made by at least two pathologists according to the World Health Organization Classification of Tumors. To detect the relationship between the rs17251221 polymorphism and breast cancer susceptibility, 231 age-matched females were recruited from the annual physical examination peoples. To analyze the association between the rs17251221 SNP and patient prognosis, 65 patients with long-term clinical follow-up were enrolled. Written, informed consent was obtained from all participants in this study, and the study was approved by the Ethical Committee of Shandong University.

DNA extraction

DNA was extracted from whole blood samples from both the patient and control groups using the QIAamp DNA mini kit (Qiagen, Hilden, Germany) according to the manufacturer's protocols. The concentration and purity of the DNA were measured using an ultraviolet spectrophotometer (GE Healthcare, Piscataway, NJ, USA). The DNA samples were stored at $-20^{\circ} \mathrm{C}$ until further use.

SNP genotyping analysis

TaqMan allelic discrimination analyses were performed according to the Applied Biosystems standard protocols (Applied Biosystems, Carlsbad, CA, USA). The TaqMan probes were synthesized by Takara (Dalian, 
China). The genotyping assay was performed using a StepOnePlus Real-Time PCR System. The following amplification conditions were used: $95^{\circ} \mathrm{C}$ for $10 \mathrm{~min}, 45 \mathrm{cycles}$ of $92^{\circ} \mathrm{C}$ for $15 \mathrm{~s}, 60^{\circ} \mathrm{C}$ for $60 \mathrm{~s}$ and $60^{\circ} \mathrm{C}$ for $30 \mathrm{~s}$. To confirm our genotyping results, several DNA samples were randomly amplified and sequenced using polymerase chain reaction (PCR) analysis. The following sequencing primers were designed: forward primer 5- GCCAATGGAGCAGCGTTCACAGA-3 and reverse primer 5-ATCCTGCCTCAG CCTCCCAAAGT -3.

Quantitative reverse-transcription PCR (qRT-PCR) analysis

Total RNA was extracted using the TRIZOL reagent, and cDNA was synthesized from $1 \mu \mathrm{g}$ of total RNA using the PrimerScript RT Reagent Kit (TaKaRa, Dalian, China). qRT-PCR was performed using the SYBR green PCR mix on a StepOnePlus Real-Time PCR System. The following primer sequences were used: 5-AAGGGGGACATTATCCTTGG-3 and 5-GCTGGGCTGCTGTTTATCTC-3. The samples were loaded in quadruplicate, and the results of each sample were normalized to $\beta$-actin. Each experiment was repeated at least three times to confirm the results.

Immunohistochemistry (IHC)

To evaluate the association between the rs17251221 polymorphism and the clinicopathological parameters, tissue microarrays were stained using the streptavidin-peroxidase-biotin (SP) method, as previously described $[15,16]$. CaSR immunoreactivity was localized to the cytoplasm and was semiquantitatively scored based on the percentage of positive cells. CaSR immunoreactivity was assigned one of the two final scores: negative ( $\leq 10 \%$ positive tumor cells) or (positive $>50 \%$ positive tumor cells). The tumor was scored positive for estrogen receptor (ER) and progestogen receptor (PR) when $\geq 10 \%$ of the tumor cells on the slide were positive for the receptor, regardless of the staining intensity. Human epidermal growth factor receptor 2 (HER2) status was evaluated according to the DAKO scores.

\section{Statistical analysis}

The allele frequencies were tested for Hardy-Weinberg equilibrium using the chi-square test [17]. A P-value $>0.05$ did not deviate from the equilibrium. The SPSS Statistics 18.0 (SPSS Inc. Chicago, Illinois, USA) software was used to analyze the data in our study. Unconditional logistic regression models were applied to analyze the relationship between the rs17251221 SNP and breast cancer susceptibility, as well as clinicopathological characteristics. Differences in patient survival were determined using the Kaplan-Meier method. The Cox hazard regression model was used to analyze the independent prognostic value of the rs 17251221 SNP. A P-value $<0.05$ was considered statistically significant.

\section{Results}

The association between the rs17251221 polymorphism and its expression in breast cancer tissues

To explore the possible functions of the rs17251221 polymorphism in breast cancer, we first examined the mRNA levels of CaSR in 25 cases $(16$ cases of AA, 7 cases of AG, 2 case of GG) of breast cancer tissues, according to the different SNP genotypes. Next, we determined the mRNA levels of CaSR in these samples using quantitative reverse-transcription PCR analysis. As shown in Figure $1 \mathrm{~A}$ and B, the average mRNA levels of CaSR were 3.495 \pm 0.403 for the GG genotype, $3.087 \pm 0.906$ for the AG genotype and $1.023 \pm 0.347$ for the AA genotype. No significant difference was observed between the $G G$ and $A G$ genotypes $(p=0.575)$. The GG and AG genotypes exhibited lower levels of CaSR than the AA genotype (both $\mathrm{p}<0.001$ ). We also detected the levels of CaSR protein in tissues with the different genotypes and found that the AG and GG genotypes expressed decreased levels of CaSR compared to the AA genotype (Fig. 2). Taken together, the G allele was associated with relatively lower levels of both CaSR mRNA and protein expression in breast cancer tissues. This suggested that the rs17251221 polymorphism maybe a functional SNP in breast cancer.

The association between the rs17251221 polymorphism and breast cancer susceptibility

To investigate whether the rs17251221 polymorphisms is a susceptibility risk factor for breast cancer, 231 healthy women and 217 breast cancer patients were enrolled in this 
A

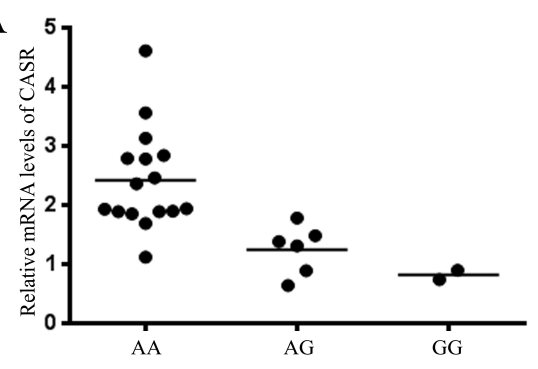

$\mathrm{B}$

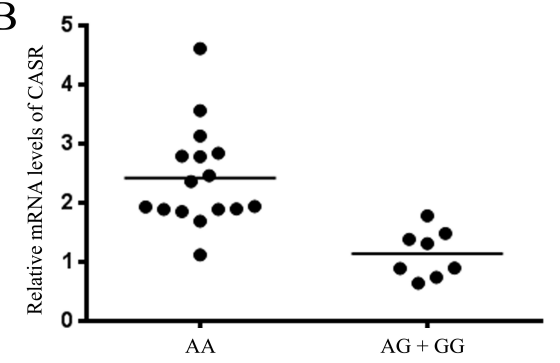

Fig. 1. The relationship between the rs17251221 polymorphism and CaSR mRNA expression in breast cancer tissues. (A) The mRNA levels of CaSR in breast cancer tissues with the AA, AG and GG genotypes. (B) The mRNA levels of CaSR in breast cancer tissues with the AA and AG+GG genotypes.

Fig. 2. The protein levels of CaSR in breast cancer tissues with the $\mathrm{AA}, \mathrm{AG}$ and $\mathrm{GG}$ genotypes.

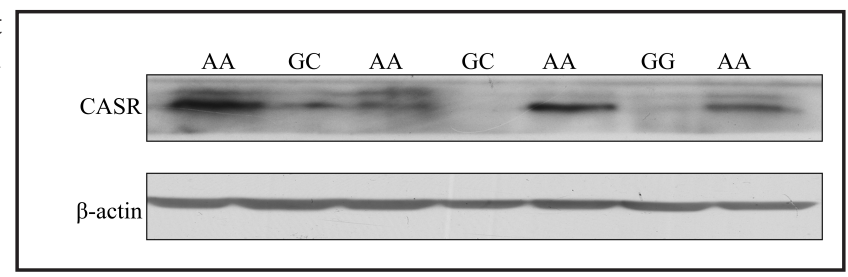

Table 1. Genotype distribution in cancer cases and controls. OR, odds ratio; $\mathrm{CI}$, confidence interval

\begin{tabular}{lllll}
\hline & $\begin{array}{c}\text { Number (\%) } \\
\text { Control }(\mathrm{n}=231)\end{array}$ & $\begin{array}{l}\text { P value } \\
(\mathrm{n}=217)\end{array}$ & OR $(95 \% \mathrm{CI})$ \\
\hline Genotypes & & & \\
$\mathrm{AA}$ & $196(84.85 \%)$ & $161(74.19 \%)$ & & \\
AG & $34(14.72 \%)$ & $47(21.66 \%)$ & 0.037 & $1.683(1.033-2.742)$ \\
GG & $1(0.43 \%)$ & $9(4.15 \%)$ & 0.007 & $10.957(1.374-87.393)$ \\
& & & & \\
AA & $196(84.85 \%)$ & $161(74.19 \%)$ & & $1.948(1.216-3.120)$ \\
AG+GG & $35(15.15 \%)$ & $56(25.81 \%)$ & 0.007 & \\
\hline
\end{tabular}

study. First, we determined whether the subjects met the Hardy-Weinberg equilibrium using a chi-squared test. For the case and control cohorts, the $\chi 2$ values were 4.85 and 0.14 , respectively (both $\mathrm{p}>0.05$ ). Therefore, the selected samples represent the whole population. The average ages of the control group and the breast cancer group were $43.79 \pm 9.78$ and $47.43 \pm 10.29$ years, respectively, and there was no significant difference between the ages of these two groups $(\mathrm{p}=0.340)$. We did not find any other statistically difference between the characteristics of the two groups.

Next, we analyzed the genotype distribution of the rs17251221 polymorphism using a TaqMan allelic discrimination assay. As shown in Table 1, we found higher proportions of the AG and GG genotypes in the cancer cases than in the control group (AG: $21.66 \%$ vs. 4.15\%; GG: $14.72 \%$ vs. $0.43 \%$, respectively). Logistic regression analysis indicated that there were significantly different distributions of the genotypes between the two groups $(p=0.037$ and $p=0.007$, respectively). Additionally, the GG and AG genotypes were associated with an increased risk of breast cancer compared to the AA genotype (OR=1.683, 95\% CI=1.0332.742; and $\mathrm{OR}=10.957,95 \% \mathrm{CI}=1.374-87.393$, respectively). As there were only 9 cancer patients and 1 control patient with the GG genotype, we combined the GG and AG genotypes in the following analyses. We found that the frequency of the $G$ allele was higher in the cancer patients $(25.81 \%)$ than in the controls $(15.15 \%)$. The analysis results showed that patients who had a G allele had a 1.948-fold higher risk for breast cancer than patients with an A allele 
Table 2. Association between rs17251221 and clinicopathological variables. ER, estrogen receptor; PR, progestogen receptor; HER2, human epidermal growth factor receptor 2; Triple-negative, ER, PR and HER2 negative

\begin{tabular}{|c|c|c|c|c|}
\hline \multirow{2}{*}{ Variables } & \multirow{2}{*}{ Number } & \multicolumn{2}{|c|}{ genotype } & \multirow[t]{2}{*}{ P value } \\
\hline & & AA & $\mathrm{AG}+\mathrm{GG}$ & \\
\hline Age & & & & 0.006 \\
\hline$\leq 45$ & 102 & $33(32.35 \%)$ & $69(67.65 \%)$ & \\
\hline$>45$ & 115 & $59(51.30 \%)$ & $56(48.70 \%)$ & \\
\hline Pathological type & & & & 0.621 \\
\hline Ductal & 171 & $78(45.61 \%)$ & $93(54.39 \%)$ & \\
\hline others & 46 & $19(41.30 \%)$ & $27(58.70 \%)$ & \\
\hline Tumor size $(\mathrm{cm})$ & & & & 0.011 \\
\hline$\leq 2$ & 132 & $47(35.61 \%)$ & $85(64.39 \%)$ & \\
\hline$>2$ & 71 & $39(54.93 \%)$ & $32(45.07 \%)$ & \\
\hline Histological grade & & & & \\
\hline Low & 79 & $37(46.84 \%)$ & $52(53.16 \%)$ & 0.243 \\
\hline High & 40 & $12(30.00 \%)$ & $28(70.00 \%)$ & \\
\hline Lymph node metastasis & & & & 0.021 \\
\hline No & 117 & $69(58.97 \%)$ & $48(41.03 \%)$ & \\
\hline Yes & 66 & $27(40.91 \%)$ & $39(59.09 \%)$ & \\
\hline ER & & & & 0.001 \\
\hline Negative & 47 & $35(74.47 \%)$ & $12(25.53 \%)$ & \\
\hline Positive & 96 & $42(64.58 \%)$ & $54(35.42 \%)$ & \\
\hline PR & & & & 0.193 \\
\hline Negative & 70 & $31(44.29 \%)$ & $39(55.71 \%)$ & \\
\hline Positive & 81 & $45(55.56 \%)$ & $36(44.45 \%)$ & \\
\hline HER2 & & & & 0.380 \\
\hline Negative & 108 & $45(41.67 \%)$ & $63(58.33 \%)$ & \\
\hline Positive & 81 & $39(48.15 \%)$ & $42(51.85 \%)$ & \\
\hline
\end{tabular}

Fig. 3. The relationship between the rs17251221 polymorphism and breast cancer prognosis according to Kaplan-Meier analysis. (A) The AG+GG genotypes of rs17251221 had shorter relapse-free survival $(\mathrm{p}<0.001)$. (B) The AG+GG genotypes of rs17251221 were associated with shorter overall survival $(p=0.015)$.
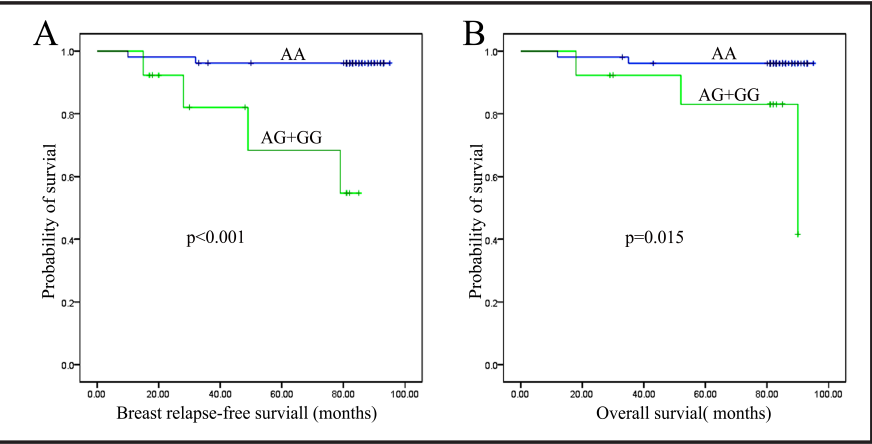

$(\mathrm{p}=0.007, \mathrm{OR}=1.948,95 \% \mathrm{CI}=1.216-3.120)$ (Table 1$)$. Taken together, our finding suggested that the $\mathrm{G}$ allele might be a risk factor for the development of breast cancer.

The association between the rs17251221 polymorphism and clinicopathological variables

We first detected the expression of CaSR protein in the clinical samples and found that the percentage of CaSR negative cases was significantly higher in the AG+GG genotypes than in the AA genotype $(\mathrm{p}=0.0316)$ (Table 2). Additionally, we summarized the association of the rs17251221 genotypes with the clinicopathological characteristics in Table 2, including the patient's age at diagnosis, tumor size, pathological type and histological grade, lymph nodal status, estrogen receptor (ER) status, progesterone receptor (PR) status and human epidermal growth factor receptor 2 (HER2) status. We found that the GG+AG genotypes were associated with the patient's age at diagnosis $(\mathrm{p}=0.006)$, tumor size $(\mathrm{p}=0.011)$, lymph node metastasis $(\mathrm{p}=0.021)$ and ER status $(\mathrm{p}=0.001)$ in the breast cancer patients, but were not associated with the histological grade, pathological type, PR status, or HER2 status. 
The association between the rs17251221 polymorphism and breast cancer prognosis

As we found that the rs17251221 polymorphism was associated with age, tumor size and lymph node metastasis, these results suggested that the rs17251221 polymorphism may be a prognostic indictor for breast cancer survival. Therefore, we evaluated the rs17251221 genotypes with respect to the disease-free survival and overall survival. As shown in Figure 3 , we found that the GG+AG genotypes of the rs17251221 SNP were correlated with a shorter disease-free survival and a shorter overall survival using Kaplan-Meier analysis of sixty-five patients $(\mathrm{p}<0.001, \mathrm{p}=0.015$, respectively). We further performed Cox proportional hazards regression analysis to investigate the independent prognostic value of the rs17251221 polymorphism. The patient's age at diagnosis, the size of the primary tumors, lymph node status, ER status, PR status, and HER-2 status were involved in the multi-analysis. However, the GG +AG genotypes of the rs17251221 SNP failed to retain its prognostic value for diseasefree survival $(p=0.114)$ and overall survival $(p=0.698)$. These data suggested that this SNP was not an independent prognostic factor.

\section{Discussion}

Breast cancer is still one of the most common malignant diseases in the world. Unfortunately, the detailed pathogenesis of breast cancer has not yet been completely elucidated. Genomic polymorphisms are widely dispersed in the human genome, and single nucleotide polymorphisms are one of the most prevalent forms of human genetic variation [18]. Recently, several genome wide association studies have reported many genetic variants that are associated with breast susceptibility [19-23]. Therefore, identifying novel functional single nucleotide polymorphisms is a novel, promising avenue for the prevention of breast cancer.

CaSR is expressed at different lesions, including in normal and fibrocystic breast duct cells, as well as ductal carcinomas of the breast [24]. Several experiments have confirmed that CaSR acts as a tumor suppressor in breast cancer. It has been reported that extracellular $\mathrm{Ca}^{2+}$ can down-regulate cell proliferation, invasion and anchorage-independent growth in cancer $[25,26]$. Recent studies showed that BRCA1 expression could increase the sensitivity of breast cancers to paclitaxel by regulating CaSR [27-29]. We investigated the rs17251221 SNP because it is one genetic variation of CaSR. Previous studies found that rs17251221 was strongly associated with serum calcium regulation [11], and it has been shown to be a susceptibility marker for stone multiplicity in nephrolithiasis [13]. Therefore, rs17251221 may be a potential functional polymorphism in breast cancer.

To confirm the above hypothesis, we first detected the mRNA levels of CaSR in breast cancer tissues with different genotypes, and we found that the GG+AG genotypes had lower mRNA and protein levels compared to the AA genotype. These data suggested that the polymorphism had an effect on CaSR expression, which may subsequently contribute to the development and progression of breast cancer. We next investigated the role of rs17251221 in breast cancer susceptibility in a Han Chinese population in a case-control study. Our data demonstrated that the $\mathrm{GG}+\mathrm{AG}$ genotypes were associated with breast cancer susceptibility. Because the ER, PR and HER statuses are well-established indices of survivability, we analyzed the relationship between CaSR and ER, PR and HER-2 in the clinical samples, and found that CaSR was significantly associated with ER status. However, we found that CaSR did not correlate with PR status or HER2 status. This may due to the small number of cases in our study, and therefore further studies enrolling a larger cohort of cases are needed to determine relationship between CaSR and PR as well as HER2 status in the future. More importantly, we found that the GG+AG genotypes were prognostic indicators for both disease-free survival and overall survival of breast cancer.

To the best of our knowledge, this is the first study to reveal that the rs17251221 polymorphism in CaSR was associated with breast cancer susceptibility and prognosis. However, further investigations are warranted to understand the precise mechanism of this 
polymorphism. Our present findings suggest that rs17251221 may play an important role in the development of breast cancer and, therefore, may be a vital prognostic indicator for breast cancer in the future.

\section{Conflicts of Interest}

The authors declare that they have no competing interests.

\section{Acknowledgements}

This work was supported by National Natural Science Foundation of China (No. 81072150; No. 81172529; No. 81272903) and Shandong Science and Technology Development Plan (No. 2012GZC22115).

\section{References}

1 Siegel R, Naishadham D, Jemal A: Cancer statistics, 2012. CA Cancer J Clin 2012;62:10-29.

-2 Mavaddat N, Antoniou AC, Easton DF, Garcia-Closas M: Genetic susceptibility to breast cancer. Mol Oncol 2010;4:174-191.

-3 Yu JC, Ding SL, Chang CH, Kuo SH, Chen ST, Hsu GC, Hsu HM, Hou MF, Jung LY, Cheng CW, Wu PE, Shen CY: Genetic susceptibility to the development and progression of breast cancer associated with polymorphism of cell cycle and ubiquitin ligase genes. Carcinogenesis 2009;30:1562-1570.

4 Miki Y, Swensen J, Shattuck-Eidens D, Futreal PA, Harshman K, Tavtigian S, Liu Q Cochran C, Bennett LM, Ding $\mathrm{W}$, et al.: A strong candidate for the breast and ovarian cancer susceptibility gene brca1. Science 1994;266:66-71.

-5 Wooster R, Bignell G, Lancaster J, Swift S, Seal S, Mangion J, Collins N, Gregory S, Gumbs C, Micklem G: Identification of the breast cancer susceptibility gene brca2. Nature 1995;378:789-792.

6 Brown EM, Gamba G, Riccardi D, Lombardi M, Butters R, Kifor O, Sun A, Hediger MA, Lytton J, Hebert SC: Cloning and characterization of an extracellular $\mathrm{Ca}^{2+}$-sensing receptor from bovine parathyroid. Nature 1993;366:575-580.

7 Pollak MR, Brown EM, Chou YH, Hebert SC, Marx SJ, Steinmann B, Levi T, Seidman CE, Seidman JG: Mutations in the human $\mathrm{Ca}^{2+}$-sensing receptor gene cause familial hypocalciuric hypercalcemia and neonatal severe hyperparathyroidism. Cell 1993;75:1297-1303.

8 Brown EM, MacLeod RJ: Extracellular calcium sensing and extracellular calcium signaling. Physiol Rev 2001;81:239-297.

9 Magno AL, Ward BK, Ratajczak T: The calcium-sensing receptor: A molecular perspective. Endocr Rev 2011;32:3-30.

10 Pidasheva S, Grant M, Canaff L, Ercan O, Kumar U, Hendy GN: Calcium-sensing receptor dimerizes in the endoplasmic reticulum: Biochemical and biophysical characterization of casr mutants retained intracellularly. Hum Mol Genet 2006;15:2200-2209.

11 Kapur K, Johnson T, Beckmann ND, Sehmi J, Tanaka T, Kutalik Z, Styrkarsdottir U, Zhang W, Marek D, Gudbjartsson DF, Milaneschi Y, Holm H, Diiorio A, Waterworth D, Li Y, Singleton AB, Bjornsdottir US, Sigurdsson G, Hernandez DG, Desilva R, Elliott P, Eyjolfsson GI, Guralnik JM, Scott J, Thorsteinsdottir U, Bandinelli S, Chambers J, Stefansson K, Waeber G, Ferrucci L, Kooner JS, Mooser V, Vollenweider P, Beckmann JS, Bochud M, Bergmann S: Genome-wide meta-analysis for serum calcium identifies significantly associated snps near the calcium-sensing receptor (casr) gene. PLoS Genet 2010;6:e1001035.

12 Reh CM, Hendy GN, Cole DE, Jeandron DD: Neonatal hyperparathyroidism with a heterozygous calciumsensing receptor (casr) r185q mutation: Clinical benefit from cinacalcet. J Clin Endocrinol Metab 2011;96:E707-712.

13 Chou YH, Woon PY, Chen WC, Hsu YW, Chang JM, Hwang DY, Chiu YC, Kuo HC, Chang WP, Hou MF, Liu ME, Chang JG, Chang WC: A genetic polymorphism (rs17251221) in the calcium-sensing receptor gene (casr) is associated with stone multiplicity in calcium nephrolithiasis. PLoS One 2011;6:e25227.

14 Jorde R, Schirmer H, Njolstad I, Lochen ML, Bogeberg Mathiesen E, Kamycheva E, Figenschau Y, Grimnes G: Serum calcium and the calcium-sensing receptor polymorphism rs17251221 in relation to coronary heart disease, type 2 diabetes, cancer and mortality: The tromso study. Eur J Epidemiol 2013;28:569-578. 
15 Zhang N, Li X, Tao K, Jiang L, Ma T, Yan S, Yuan C, Moran MS, Liang F, Haffty BG, Yang Q: Bcl-2 (-938c > a) polymorphism is associated with breast cancer susceptibility. BMC Med Genet 2011;12:48.

16 Li X, Kong X, Chen X, Zhang N, Jiang L, Ma T, Yang Q: Laptm4b allele *2 is associated with breast cancer susceptibility and prognosis. PLoS One 2012;7:e44916.

-17 Rodriguez S, Gaunt TR, Day IN: Hardy-weinberg equilibrium testing of biological ascertainment for mendelian randomization studies. Am J Epidemiol 2009;169:505-514.

18 Wang DG, Fan JB, Siao CJ, Berno A, Young P, Sapolsky R, Ghandour G, Perkins N, Winchester E, Spencer J, Kruglyak L, Stein L, Hsie L, Topaloglou T, Hubbell E, Robinson E, Mittmann M, Morris MS, Shen N, Kilburn D, Rioux J, Nusbaum C, Rozen S, Hudson TJ, Lipshutz R, Chee M, Lander ES: Large-scale identification, mapping, and genotyping of single-nucleotide polymorphisms in the human genome. Science 1998;280:1077-1082.

19 Ahmed S, Thomas G, Ghoussaini M, Healey CS, Humphreys MK, Platte R, Morrison J, Maranian M, Pooley KA, Luben R, Eccles D, Evans DG, Fletcher O, Johnson N, dos Santos Silva I, Peto J, Stratton MR, Rahman N, Jacobs K, Prentice R, Anderson GL, Rajkovic A, Curb JD, Ziegler RG, Berg CD, Buys SS, McCarty CA, Feigelson HS, Calle EE, Thun MJ, Diver WR, Bojesen S, Nordestgaard BG, Flyger H, Dork T, Schurmann P, Hillemanns P, Karstens JH, Bogdanova NV, Antonenkova NN, Zalutsky IV, Bermisheva M, Fedorova S, Khusnutdinova E, Kang D, Yoo KY, Noh DY, Ahn SH, Devilee P, van Asperen CJ, Tollenaar RA, Seynaeve C, Garcia-Closas M, Lissowska J, Brinton L, Peplonska B, Nevanlinna H, Heikkinen T, Aittomaki K, Blomqvist C, Hopper JL, Southey MC, Smith L, Spurdle AB, Schmidt MK, Broeks A, van Hien RR, Cornelissen S, Milne RL, Ribas G, Gonzalez-Neira A, Benitez J, Schmutzler RK, Burwinkel B, Bartram CR, Meindl A, Brauch H, Justenhoven C, Hamann U, Chang-Claude J, Hein R, Wang-Gohrke S, Lindblom A, Margolin S, Mannermaa A, Kosma VM, Kataja V, Olson JE, Wang X, Fredericksen Z, Giles GG, Severi G, Baglietto L, English DR, Hankinson SE, Cox DG, Kraft P, Vatten LJ, Hveem K, Kumle M, Sigurdson A, Doody M, Bhatti P, Alexander BH, Hooning MJ, van den Ouweland AM, Oldenburg RA, Schutte M, Hall P, Czene K, Liu J, Li Y, Cox A, Elliott G, Brock I, Reed MW, Shen CY, Yu JC, Hsu GC, Chen ST, Anton-Culver H, Ziogas A, Andrulis IL, Knight JA, Beesley J, Goode EL, Couch F, Chenevix-Trench G, Hoover RN, Ponder BA, Hunter DJ, Pharoah PD, Dunning AM, Chanock SJ, Easton DF: Newly discovered breast cancer susceptibility loci on 3p24 and 17q23.2. Nat Genet 2009;41:585-590.

20 Hunter DJ, Kraft P, Jacobs KB, Cox DG, Yeager M, Hankinson SE, Wacholder S, Wang Z, Welch R, Hutchinson A, Wang J, Yu K, Chatterjee N, Orr N, Willett WC, Colditz GA, Ziegler RG, Berg CD, Buys SS, McCarty CA, Feigelson HS, Calle EE, Thun MJ, Hayes RB, Tucker M, Gerhard DS, Fraumeni JF Jr, Hoover RN, Thomas G, Chanock SJ: A genome-wide association study identifies alleles in fgfr2 associated with risk of sporadic postmenopausal breast cancer. Nat Genet 2007;39:870-874.

-21 Zheng W, Long J, Gao YT, Li C, Zheng Y, Xiang YB, Wen W, Levy S, Deming SL, Haines JL, Gu K, Fair AM, Cai Q, Lu W, Shu XO: Genome-wide association study identifies a new breast cancer susceptibility locus at 6q25.1. Nat Genet 2009;41:324-328.

-22 Peto J, Collins N, Barfoot R, Seal S, Warren W, Rahman N, Easton DF, Evans C, Deacon J, Stratton MR: Prevalence of brca1 and brca2 gene mutations in patients with early-onset breast cancer. J Natl Cancer Inst 1999;91:943-949.

23 Lichtenstein P, Holm NV, Verkasalo PK, Iliadou A, Kaprio J, Koskenvuo M, Pukkala E, Skytthe A, Hemminki K: Environmental and heritable factors in the causation of cancer--analyses of cohorts of twins from sweden, denmark, and finland. N Engl J Med 2000;343:78-85.

-24 Cheng I, Klingensmith ME, Chattopadhyay N, Kifor O, Butters RR, Soybel DI, Brown EM: Identification and localization of the extracellular calcium-sensing receptor in human breast. J Clin Endocrinol Metab 1998;83:703-707.

25 Liu G, Hu X, Chakrabarty S: Calcium sensing receptor down-regulates malignant cell behavior and promotes chemosensitivity in human breast cancer cells. Cell Calcium 2009;45:216-225.

-26 Chakrabarty S, Radjendirane V, Appelman H, Varani J: Extracellular calcium and calcium sensing receptor function in human colon carcinomas: Promotion of e-cadherin expression and suppression of betacatenin/tcf activation. Cancer Res 2003;63:67-71.

27 Promkan M, Liu G, Patmasiriwat P, Chakrabarty S: Brca1 suppresses the expression of survivin and promotes sensitivity to paclitaxel through the calcium sensing receptor (casr) in human breast cancer cells. Cell Calcium 2011;49:79-88.

28 Promkan M, Liu G, Patmasiriwat P, Chakrabarty S: Brca1 modulates malignant cell behavior, the expression of survivin and chemosensitivity in human breast cancer cells. Int J Cancer 2009;125:2820-2828.

29 Singh N, Promkan M, Liu G, Varani J, Chakrabarty S: Role of calcium sensing receptor (casr) in tumorigenesis. Best Pract Res Clin Endocrinol Metab 2013;27:455-463. 